\title{
Factors Affecting Profitability of Smallholder Vegetable Farmers in the Shiselweni Region, Kingdom of Eswatini (Swaziland)
}

\author{
Lovemore M. Rugube $^{1}$, Sifisile P. Nsibande ${ }^{1}$, Michael T. Masarirambi ${ }^{2} \&$ Patricia J. Musi $^{3}$ \\ ${ }^{1}$ Department of Agricultural Economics and Agribusiness Management, Faculty of Agriculture, University of \\ Eswatini, PO Luyengo, Luyengo M205, Eswatini \\ ${ }^{2}$ Department of Horticulture, Faculty of Agriculture, University of Eswatini, PO Luyengo, Luyengo M205, \\ Eswatini \\ ${ }^{3}$ Department of Consumer Science Education and Community Development, Faculty of Consumer Sciences, \\ University of Eswatini, PO Luyengo, Luyengo M205, Eswatini \\ Correspondence: Lovemore M. Rugube, Department of Agricultural Economics and Agribusiness Management, \\ Faculty of Agriculture, University of Eswatini, PO Luyengo, Luyengo M205, Eswatini. Tel: 268-7652-9804. \\ E-mail: ruguubelm@gmail.com
}

\author{
Received: October 24, 2018 Accepted: November 8, 2018 Online Published: January 28, 2019 \\ doi:10.5539/sar.v8n1p104 URL: https://doi.org/10.5539/sar.v8n1p104
}

\begin{abstract}
Agriculture is the main anchor of the Eswatini economy and profitability in this sector still remains vital for sustainable development of the economy. This study investigated the factors affecting profitability of smallholder vegetable farmers in the Shiselweni region. Primary data was obtained using a structured questionnaire and personal interviews from 60 vegetable farmers. Data was analyzed using descriptive statistics, enterprise budget, profitability ratios and multiple linear regression models. The SPSS software was used. The results showed that the mean age of the vegetable farmers was found to be 50.5 years, the mean household size was 8 people, mean farming experience was 3 years, mean farm size was 3 hectares and the majority of the farmers had high school education. The net income of smallholder vegetable farmers was E5810.30. The results of the multiple linear regression analysis revealed that land size, gender, household size, had a direct relationship with profitability of vegetable production while age, education, experience, income and labour had a negative relationship. Farmers requested that the subsidized farm inputs should arrive on time, new engines be bought for them and dams be constructed to generate irrigation water in winter.
\end{abstract}

Keywords: farm profitability, smallholder farmers, vegetable irrigation, sustainable economic growth and development

\section{Introduction}

Agriculture dominates the economy of Eswatini and it has a great impact and significance on output and income. In order to improve rural income and satisfy consumer demand for food and raw materials by the urban population, agricultural production should increase sustainably (FAO, 2008). Supporting agricultural productivity contributes to industrial growth by providing relatively cheap raw material, employment opportunities, capital investment, foreign exchange and markets for consumer goods and reduces the high dependence on imported and costly agricultural products.

Agriculture is the backbone of the country's economy and the driver for achieving the overall objectives of development. The agricultural sector accounts for $10.3 \%$ of the country's Gross Domestic Product (GDP). Agriculture is also a major source of income, employment and food for rural people with over $70 \%$ of the population fully dependent on this sector for livelihood (Thompson, 2011). Smallholder farmers are, in most cases, resource-poor (Blackwood \& Lynch, 1994). However their contribution to food security through vegetable production is crucial (FAO, 2008; Eigenbrod and Gruda, 2015; Ojiewo et al., 2015). Food availability, accessibility, utilization and stability are the four internationally recognized pillars of food security (FAO 2008; Ojiewo et al., (2015). Agriculture significantly contributes to the development of the country's economy by providing the needed raw materials for agro-based industries that make up the major support of the manufacturing sector (Panin and Hlope, 2013; Xaba and Masuku, 2013). 
In Eswatini, smallholder farmers are found mainly on SNL where they practise mixed farming which involves growing crops and rearing livestock. Smallholder farmers are those farmers that produce crops and raise livestock on a small piece of land while using available resources which exclude expensive modern technology and machinery (Bonti-Ankomah, 2001).

They are usually labour- intensive, with the usage of cattle for traction and ploughing. Most of the smallholder farmers live under the poverty datum line, lack formal education and access to improved farm inputs and modernized farming technologies, resulting in reduced production and yields which dwindles the profits of farmers (Thompson, 2011).

Vegetables are edible portions of plants that can either be root, stem, leafy green, flower, stalk or fruit (Yamaguchi, 1983; Peirce, 1987; Norman, 1992. They consist of two main types: baby vegetables and conventional vegetables, with the main difference being that baby vegetables are smaller and harvested before they reach full maturity (Xaba and Masuku, 2013). However not much work has been carried out on profitability of producing vegetables in Eswatini. About $80 \%$ of the Swazi population lives on Swazi Nation Land (SNL). They derive their livelihood from subsistence agricultural production (Thompson, 2011).

Eswatini faces shortage of locally produced vegetables. About $70 \%$ of consumed vegetables in the country are imported from South Africa. The NAMBoard Annual report of 2015/16 attributed the decline of farmer's participation in vegetable production to high input costs, climate change and other factors. The negative impact of climate change on agricultural productivity has previously been reported (FAO, 2008; Manyatsi et al., 2010; Oseni \& Masarirambi, 2011; Manyatsi et al., 2013). Fruits and vegetable production is negatively impacted by climate change yet Governments and public health officials are urging the public to eat more fruits and vegetables to contribute to a healthy diet (Lan \& Dobson, 2017). This causes the country to import most of the vegetables it needs from overseas with the attendant increase in market prices. This greatly discourages the remaining farmers from producing vegetables for commercial purposes as it becomes difficult to compete with the imported vegetables. Sometimes post-harvest losses are incurred rapidly. Post-harvest losses of vegetables under prevailing tropical conditions have previously been reported (Wills et al., 2018) and that there is need to prevent such losses.

Therefore, the questions posed in this study were:

1. What are the socioeconomic characteristics of vegetable farmers in the Shiselweni region?

2. How profitable is vegetable production in the Shiselweni region?

3. What are the constraints faced by vegetable farmers in the Shiselweni region?

The main objective of the study was to analyze the factors affecting the profitability of smallholder vegetable farmers in Eswatini.

\section{Methodology}

\subsection{Study Area}

The study was conducted at Nhlangano in the Shiselweni region in Eswatini (Figure 1). The study area is a place which was found to be densely populated with smallholder vegetable farmers. The Shiselweni region is in the southern part of Eswatini which receives relatively higher rainfall compared to other areas. Farmers engaged in the production of vegetables at Maseyisini, Matimatima, Nyamane, Madulini, Nkhungwini and Mpatheni areas were sampled as participants. 


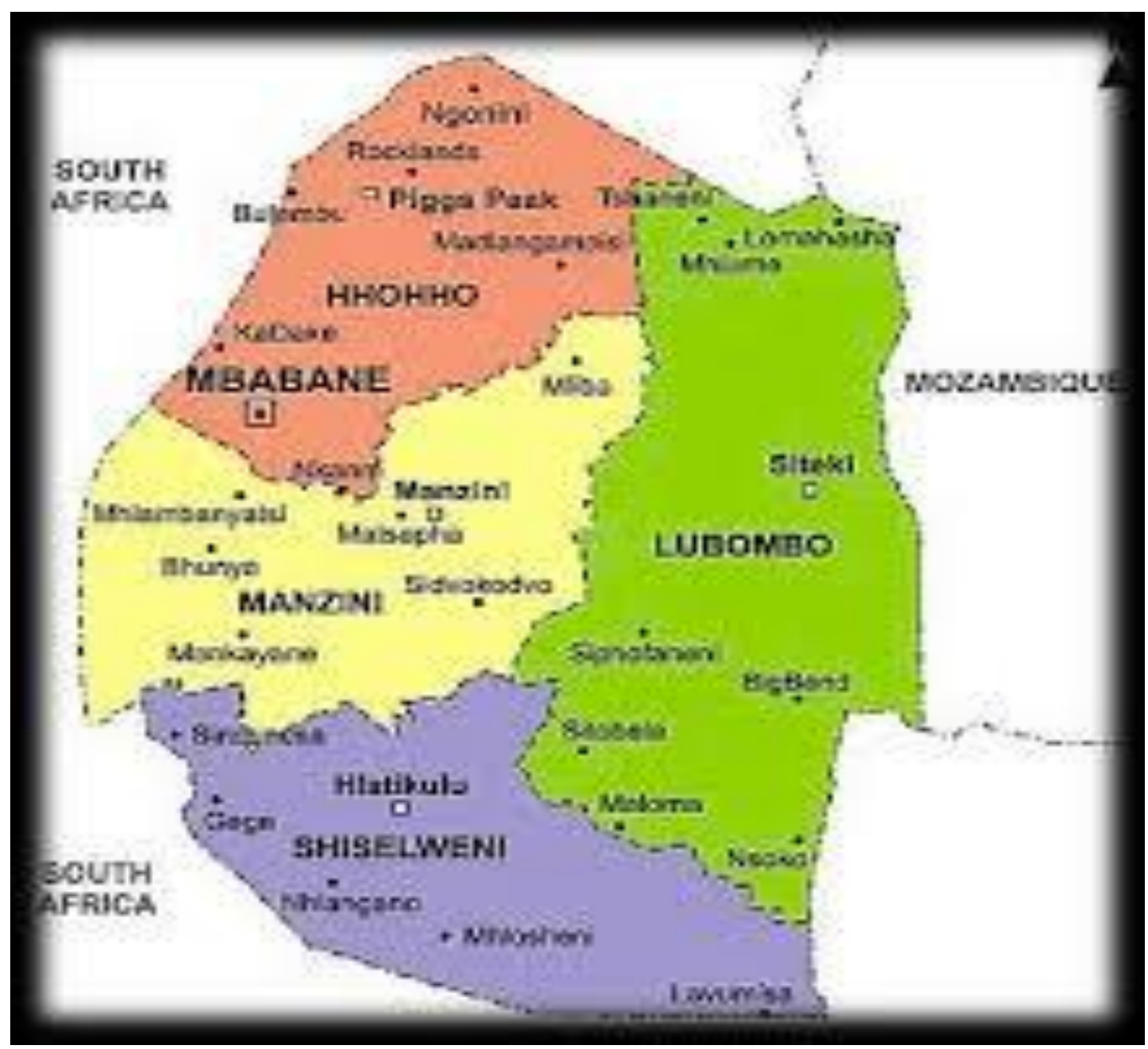

Figure 1. Map showing the Shiselweni region in the South

\subsection{Research Design}

A descriptive cross-sectional research design was employed in the study with an aim of describing the profitability of vegetables farming in Swaziland. Cross-sectional study involves using different groups of people who differ in variables of interest but share other characteristics such as socio-economic status, educational background and ethnicity (Blackwood and Lynch, 1994).

\subsection{Sampling Procedure}

The sampling methods used to get the required sample included purposive sampling and simple random sampling (Van Dalen, 1979; Krejcie \& Morgan, 1970; Connely, 2008; Salkind, 2012). Purposive sampling technique was used to obtain the Tinkhundla to be involved in the study. A simple random sampling was used to select a sample size of 60 farmers. Conventional vegetables (cabbage, carrot, onion, spinach and green pepper) were studied. These crops account for the major proportion of vegetables produced in the country and needed in constant supply in the markets.

\subsection{Data Collection}

Data was collected through personal interviews using questionnaires with both open and close ended questions (Salkind, 2012). However, supplementary information was collected through observations and interview of some key participants apart from selected respondents. Data was collected between the period of January 2018 and March, 2018.

\subsection{Data Analysis}

The Statistical Package for Social Sciences (SPSS) was used to carry out data analysis (Lavsque, 2007). Data 
was analyzed using descriptive statistics. Frequencies, percentages and standard deviation were generated from the analysis and used to describe the demographic characteristics of vegetable farmers which included age, gender, level of education, farm size. To determine profitability, gross margins per individual household were calculated. This is the income earned minus the total variable costs. This gives the gross profit. Profitability ratios used included:

\section{Cost/Benefit Ratio}

Cost Benefit Ratio $=$ Total Revenue $/$ Total Costs

\section{Operating expense Ratio}

(Operating expenses / gross revenue) $* 100$

\section{Net Farm Income Ratio}

Net farm income/ gross farm returns

\subsection{Econometric Model}

To determine the factors affecting profitability of vegetable farming, the following multiple linear regression model was used:

$$
Y=\beta_{0}+\beta_{1} X_{1}+\beta_{2} X_{2}+\beta_{3} X_{3}+\beta_{4} X_{4}+\beta_{5} X_{5}+\beta_{6} X_{6}+\beta_{7} X_{7}+\beta_{8} X_{8}+\varepsilon
$$

Where:

$\mathrm{Y}=$ Profitability (profit/ha)

$\beta_{0}=$ Constant

$\beta_{1} \ldots \beta_{8}=$ Parameters to be estimated

$\mathrm{X}_{1}=$ Size of land used for vegetable production

$\mathrm{X}_{2}=$ Age of farmers

$\mathrm{X}_{3}=$ Gender (female and male)

$\mathrm{X}_{4}=$ Education level

$\mathrm{X}_{5}=$ Labour

$\mathrm{X}_{6}=$ Farming experience (years)

$\mathrm{X}_{7}=$ Income

$\mathrm{X}_{8}=$ Household size (number of persons)

$\varepsilon=$ Random error term.

\subsection{Explanation of Variables and a Priori Expectations}

Profitability (Y): This is the dependent variable and measured using profit per hectare (Emalangeni [E] per ha). It was assumed that it is determined by all the explanatory variables included in the model.

Size of land used for vegetable production $\left(\mathrm{X}_{1}\right)$ : An increase in the size of land for vegetable production increases the production of vegetables, thus increasing profit margins. A positive relationship is expected between the size of land used for vegetable production and profitability.

Age of farmers $\left(\mathrm{X}_{2}\right)$ : This is a representative of the level of knowledge that the farmer has supposedly gained. Experience comes with age and therefore, a positive relationship is expected between age and profitability.

Gender (female and male) $\left(\mathrm{X}_{3}\right)$ : A positive relationship is anticipated between male farmers and profitability because they are usually stronger and they are the bread winners in most families.

Education level $\left(\mathrm{X}_{4}\right)$ : The level of education is crucial in vegetable production as it is linked to understanding the vegetable farming business. This assumption results in good agricultural practices (GAP) and management of vegetables hence improving yield and profits.

Labour $\left(\mathrm{X}_{5}\right)$ : Source of labour plays an important role in the profitability of vegetable farming. It is expected that skilled labour will improve profitability of vegetable farming as the use of the skills improve vegetable farming thus a positive relationship between labour and profitability is expected.

Farming experience $\left(\mathrm{X}_{6}\right)$ : A positive relationship is expected between farming experience and profitability.

Source of income $\left(\mathrm{X}_{7}\right)$ : It is assumed that a farmer that is fully dependent on vegetable production as a source of 
income is most likely to make the highest profit as all resources and attention are focused on the vegetable business than a farmer who has an extra income.. Therefore a positive relationship is expected between source of income and profitability.

Household size $\left(\mathrm{X}_{8}\right)$ : Household size has been described as the most important determinant of labour for family farms. A positive relationship is expected between household size and profitability.

\section{Results and Discussion}

\subsection{The Demographic Characteristics of Respondents}

The demographic characteristics of the respondents considered included sex, educational level, age, household size, experience and land size. Table 1 shows the demographic characteristics of the vegetable farmers in the study area.

Table 1. Demographic characteristics of respondents

\begin{tabular}{lll}
\hline Characteristics & Frequency & Percentages $\mathbf{\%})$ \\
\hline Sex & & \\
\hline Male & 34 & 56.7 \\
Female & 26 & 43.3 \\
Total & 60 & 100.0 \\
Education Level & & \\
Primary & 16 & 26.7 \\
Secondary & 4 & 6.6 \\
High School & 27 & 45.0 \\
Tertiary & 13 & 21.7 \\
Total & 60 & 100 \\
\hline Characteristics & Frequency & Percentages $\mathbf{\%})$ \\
\hline Age & & \\
\hline 25-35 years & 14 & 23.3 \\
36-45 years & 11 & 18.3 \\
46-55 years & 21 & 35.0 \\
56-65 years & 10 & 16.7 \\
$>65$ years & 4 & 6.7 \\
Total & 60 & 100 \\
\hline Household size & & \\
\hline 1-5 members & 17 & 28.3 \\
6-10 members & 33 & 55.0 \\
11-15 members & 9 & 15.0 \\
$>15$ members & 1 & 1.7 \\
Total & 60 & 100 \\
\hline Experience & & \\
\hline 1-5 years & 28 & 46.7 \\
6-10 years & 24 & 40.0 \\
11-15 years & 5 & 8.3 \\
$>$ 15 years & 3 & 5.0 \\
Total & 60 & 100 \\
\hline Characteristics & Frequency & Percentages $\mathbf{\%})$ \\
\hline Land size & & \\
\hline$<1$ ha & 3 & 5.0 \\
1-5 hectares & 41 & 68.3 \\
$>5$ hectares & 16 & 26.7 \\
Total & 60 & 100 \\
\hline & & \\
\hline
\end{tabular}

The majority (56.7\%) of the farmers were males and most of them (35\%) were between the ages of $46-55$ years (Table, 1). Those between the ages of $25-35$ were $23.3 \%$, those between the ages of $36-45$ were $18.3 \%$, those between $56-65$ years were $16.7 \%$ while those above 65 years were $6.7 \%$. The mean age of the vegetable farmers was found to be 50.5 , which is a clear indicator that vegetable farming in the Shiselweni is dominated by active 
farmers who are still in their productive stage of life.

The majority $(45.0 \%)$ of the farmers had high school education, with $26.7 \%$ of them having ended at primary school level, only $6.6 \%$ could not exceed secondary school while $21.7 \%$ went to tertiary institutions for higher learning (Table 1).

The table also indicates the farming experience of the vegetable farmers. It depicts that a majority $(46.7 \%)$ had an experience of $1-5$ years, followed by $40 \%$ of farmers with experience of $6-10$ years, while $8.3 \%$ of the farmers having a farming experience of 11-15 years and only 5\% were highly experienced at over 15 years of vegetable production. The mean farming experience was 3 years, which means that the majority of farmers in the Shiselweni region were relatively still new in the farming business.

Most (55.0\%) of the farmers had 6-10 family members in their household, with $28.3 \%$ having 1-5 members, only $15 \%$ having 11-15 members and a very small percentage (1.7\%) who had members greater than 15 (Table 1). Thus the farmers had an average (mean) of 8 members which they were able to take care of and support with the income they received from farming.

Also worth noting is the size of the land for the farmers. A majority $(68.3 \%)$ had a reasonable amount of land (1-5 ha) which they were able to fully utilize with the available resources, with the smallest amount of land $(<1$ ha) being owned by only $5 \%$ of the farmers while $26.7 \%$ had land greater than 5 hectares (Table 1 ).

\subsection{Vegetables Grown}

The commonly grown vegetables within the study area were onions, cabbages, spinach and green pepper (Figure 1). The figure shows that more than half $(80 \%)$ of the farmers grew onions, while $73.6 \%$ of the farmers grew spinach, $71.7 \%$ grew cabbages, $64.9 \%$ grew green pepper and $56 \%$ of the farmers grew carrots.

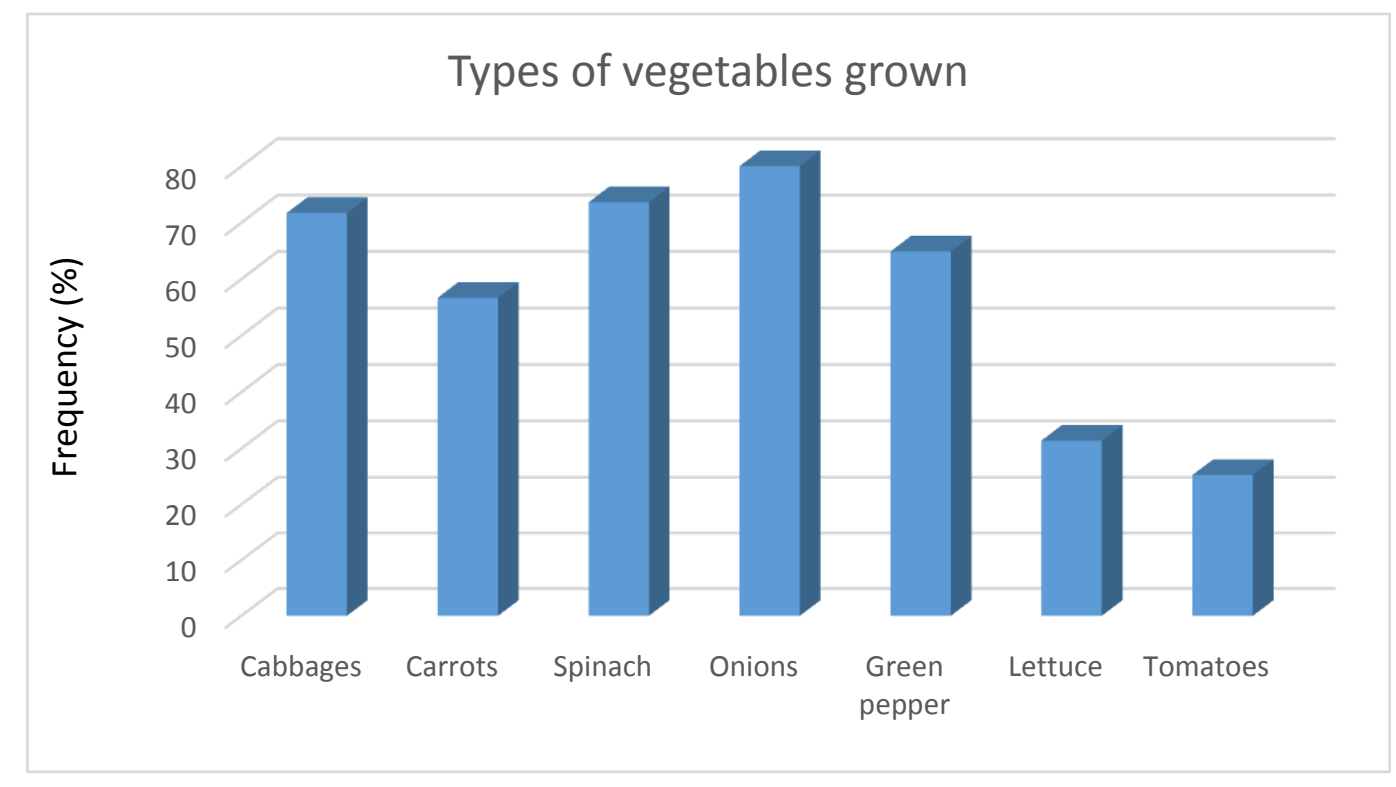

Figure 1. Types of vegetables grown

\subsection{Description of Farm Activities}

Table 2 shows that all vegetable farmers within the study area had an irrigation system even though some had systems that were highly depreciated over time. . All the farmers used sprinklers for irrigating their vegetables and that the farmers drew water using engines. The results also show that a majority (55\%) of the farmers did not use chemicals to control insect pests, diseases and weeds. This was due to the fact they would order farm inputs including the costly herbicides at a subsidized price from the regional development areas (RDA) and they would get them very late when their produce had reached maturity. Worth noting in Table 2 is that most of the farmers (68\%) used fertilizers frequently while the rest (32\%) used it occasionally or when they had the capital to buy the inputs. Alternatively they used manure for vegetable production. Good yields of vegetables have previously been reported with the use of manure (Masarirambi et al., 2012a, b, c). 
Table 2. Description of farm activities

\begin{tabular}{lll}
\hline Characteristics & Frequency & Percentage (\%) \\
\hline Sprinklers & 60 & 100 \\
Chemical users & 27 & 45 \\
Non chemical users & 33 & 55 \\
Total & 60 & 100 \\
Herbicide users & 27 & 45 \\
Non herbicide users & 33 & 55 \\
Total & 60 & 100 \\
Fertilizer users & 41 & 68 \\
Non fertilizer users & 19 & 32 \\
Total & 60 & 100 \\
Market & 11 & 18 \\
No market & 49 & 82 \\
Total & 60 & 100 \\
\hline Where they sell & & \\
Door to door selling & 15 & 25 \\
Village market & 32 & 53 \\
Local supermarkets & 13 & 22 \\
Total & 60 & 100 \\
\hline Transport to market & & \\
Hire van & 9 & 15 \\
In sacks using wheelbarrows & 22 & 37 \\
Local public transport & 29 & 48 \\
Total & 60 & 100 \\
\hline
\end{tabular}

A greater portion of the farmers $(82 \%)$ had no formal market to sell their produce (vegetables). They mainly $(53 \%)$ sold their vegetables at the local village market (vending), while some (25\%) used the door-to-door method of selling vegetables and a minority of the farmers (22) supplied vegetables to local supermarkets. Prices of vegetables in supermarkets tend to be relatively high (Lan \& Dobson, 2017). About $48 \%$ of the farmers transported their produce using public transport, 37\% in sacks using wheelbarrows while $15 \%$ hired a van when asked to supply the local supermarkets as they had to deliver very early in the morning

\subsection{Description of Business Finances}

Table 3 shows the descriptive statistics of the business finances. A larger number of farmers $(56.7 \%)$ used personal savings to finance their business, while $33.3 \%$ sourced capital from the association they were part of, $6.7 \%$ obtained their funding from their cooperative while only $3.3 \%$ obtained funding from the bank. The results also show that $76.7 \%$ of the farmers did not apply for bank loans for fear of high interest rates and because they lacked collateral for the loan. Lack of collateral has previously been reported as a challenge facing youth involved in agribusiness in the country (Musi et al., 2018). About $61.7 \%$ of the farmers reported that they obtained credit of between E5000 - E7000 to finance their business, and only 38.3\% were given between E2000 - E4000 to finance their business. The purpose of the credit was to purchase inputs and for operational purposes by most of the vegetable farmers (36.7\%), with some (35\%) arguing that they used the credit to buy the inputs, while fencing their land was a priority to $15 \%$ of the farmers. About $15.5 \%$ reported that they purchased inputs and fenced their land when they acquired credit from the banks or other financial institutions. 
Table 3. Description of business finances

\begin{tabular}{lll}
\hline Characteristics & Frequency & Percentages (\%) \\
\hline Source of finance & & \\
\hline Personal savings & 34 & 56.7 \\
Bank loan & 2 & 3.3 \\
Cooperatives & 4 & 6.7 \\
Association & 20 & 33.3 \\
Total & 60 & 100 \\
Applied for credit & 14 & 23.3 \\
Did not apply for credit & 46 & 76.7 \\
Total & 60 & 100 \\
\hline Amount of credit & & \\
\hline 2000 - 4000 & 23 & 38.3 \\
5000-7000 & 37 & 61.7 \\
Total & 60 & 100 \\
\hline Purpose of credit & & \\
\hline Buying inputs & 21 & 35 \\
Fencing & 8 & 13.3 \\
Buying inputs and fencing & 9 & 15 \\
Buying inputs and operational purpose & 22 & 36.7 \\
Total & 60 & 100 \\
\hline
\end{tabular}

Seeds accounted for $24.3 \%$ of the total variable costs (Table 4). This is an indication that seeds consumed the greater proportion of the total variable costs followed by irrigation which accounted for $22.6 \%$. Seeds are the most important of the farm inputs in vegetable production (George, 1999; MacDonald and Copeland, 1998; Turner, 2010; Brodal and Asdal, 2018). Fertilizer is also an important input in vegetable production which accounted for $16 \%$ of the total variable costs.

\subsection{Estimated Enterprise Budget}

Table 4 shows that the gross revenue, total cost and gross margin per hectare were E12735.92, E6925.68 and E5810.30 respectively. This shows that vegetable production in the study area was profitable. Previously studies have been carried out on profitability of some farming enterprises in Swaziland (Dlamini et al., 2010; Masuku, 2011; Dlamini \& Masuku, 2013). It is crucial that a farming activity be profitable.

Table 4. Estimated enterprise budget for vegetable production per hectare

\begin{tabular}{lll}
\hline Item & Value (E) & Percentage (\%) \\
\hline Revenue & & \\
\hline Sale of vegetables & $\mathbf{1 2 7 3 5 . 9 2}$ & \\
\hline Variable Costs & & \\
\hline Ploughing & 430.00 & 6.2 \\
Harrowing & 214.98 & 3.1 \\
Seeds/seedlings & 1684.72 & 24.3 \\
Fertilizer & 1105.32 & 16 \\
Chemicals & 902.54 & 13 \\
Labour & 517.39 & 7.5 \\
Packaging & 125.50 & 1.8 \\
Transport & 378.25 & 5.5 \\
Irrigation & 1566.98 & 22.6 \\
\hline Total Variable Costs & $\mathbf{6 9 2 5 . 6 8}$ & \\
\hline Gross Return & $\mathbf{5 8 1 0 . 3 0}$ & \\
\hline
\end{tabular}

Estimated enterprise budget for vegetable production per hectare

\section{Profitability Ratios}

These ratios are indicators that are used to assess a firm's profitability and performance record. 


\section{Revenue Benefit Ratio}

Cost Benefit Ratio $=$ Total Revenue $/$ Total Cost

$12735.92 / 6925.68$

\subsection{4}

The benefit cost ratio of 1.84 means that for every E1.00 a farmer invested in the production of vegetables in the study area, the return was E1. 84. This shows that vegetable production was very profitable. Farming enterprises need to be profitable for them to be worthwhile (Dlamini et al., 2010; Masuku, 2011; Dlamini \& Masuku, 2013; Musi et al., 2018)

\section{Operational Ratios}

Operation ratios are a reflection of the distribution of gross revenue or production value to operating expenses, depreciation, interest and net farm income. The ratios vary depending on the use of gross revenue.

\section{Operating Expense Ratio}

Operating expenses/gross revenue*100

$6925.68 / 12735.92$

$0.544 * 100$

\section{$54.4 \%$}

The ratio stipulates that $54.4 \%$ of gross revenue was used to cover operating expenses.

\section{Net Farm Income Ratio}

Net Farm Income/Gross farm returns*100

$5810.30 / 12735.92$

$0.456 * 100$

$45.6 \%$

A ratio of 0.456 indicates that $45.6 \%$ of gross revenue went to owner's equity and unpaid labour and management costs.

\subsection{Multiple Regression Estimates of Factors Affecting the Profitability of Vegetable Production}

Multiple linear regression was used to identify factors affecting profitability of vegetable production. Regression and correlation procedures can be classified according to the number of variables involved and the form of the functional relationship between the dependent variable and the independent variables (Gomez and Gomez, 1984; Salkind, 2012). Gross margin per hectare was used to measure profitability. In order to identify the factors affecting profitability of smallholder vegetable production, the profitability of the vegetable farmers was regressed on the following dependent variables: Land size $\left(\mathrm{X}_{1}\right)$, Age $\left(\mathrm{X}_{2}\right)$, Gender $\left(\mathrm{X}_{3}\right)$, Education $\left(\mathrm{X}_{4}\right)$, Experience $\left(\mathrm{X}_{5}\right)$, Source of income $\left(\mathrm{X}_{6}\right)$, Labour $\left(\mathrm{X}_{7}\right)$ and Household size $\left(\mathrm{X}_{8}\right)$. The results of the regression analysis are presented in Table 4.

Table 4. Multiple regression for factors affecting profitability of vegetable production

\begin{tabular}{llll}
\hline Model & B & T-statistics & P-value \\
\hline Constant & 4.599 & 4.675 & 0.000 \\
Land size & 0.830 & 3.212 & $0.002^{* *}$ \\
Age & -0.46 & -0.455 & 0.651 \\
Gender & 0.283 & 1.222 & $0.227^{*}$ \\
Education & -0.65 & -0.654 & 0.516 \\
Household size & 0.250 & 1.280 & $0.206^{*}$ \\
Experience & -0.32 & -0.182 & 0.856 \\
Source of income & -6.61 & -4.610 & $0.000^{* *}$ \\
Labour & -2.557 & -4.523 & $0.000^{* *}$ \\
\hline
\end{tabular}

R-Square $=\mathbf{0 . 6 5 7}$, Adjusted R-Square $=\mathbf{0 . 6 0 4}, \mathrm{F}$ Value $=\mathbf{1 2 . 2 2 7}$

$*=$ significant at $5 \%$ level

***=significant at $1 \%$ level

The results presented in Table 4 show that land size $\left(\mathrm{X}_{1}\right)$, income $\left(\mathrm{X}_{7}\right)$ and labour $\left(\mathrm{X}_{5}\right)$ had a direct relationship 
with profitability of vegetable production due to their level of significance that is at $1 \%$ while age $\left(\mathrm{X}_{2}\right)$, gender $\left(\mathrm{X}_{3}\right)$, education level $\left(\mathrm{X}_{4}\right)$ experience $\left(\mathrm{X}_{6}\right)$ and household size $\left(\mathrm{X}_{8}\right)$ had a reduced relationship due to their level of significance (5\%). The R-square value of 0.657 implies that $65.7 \%$ of variation in net revenue of smallholder vegetable farmers was accounted for by the joint effect of the independent variables used in the model.

The F-ratio of 12.227 with a p-value of 0.000 indicates that the model provided a good fit for the data at $1 \%$ level of significance. Land size had a positive relationship with profitability and was significant at $1 \%$ level of significance. This means that a 1 hectare increase in land size allocated to vegetable production could increase profits by $0.83 \%$. This could be due to the fact that when size of land increases, total production increases, therefore, profitability is also expected to increase. The results also indicate that household size and experience had a positive relationship with profitability. This means that the more the household size increased and experience increased the more the profitability.

\subsection{Challenges Faced by Vegetable Farmers}

The majority (33\%) of the farmers reported that they lacked skills and training (Table 5). High costs and limited access to inputs was a problem to $68.3 \%$ of the farmers, while $75 \%$ of them were faced with a major threat of unreliable water facilities which hindered the growth of their vegetables (Table 5). Many (73.3\% ) of the farmers were affected by increase in global food prices while $70 \%$ of them were faced with inadequate agricultural extension services that could help them improve production in order to increase profitability. A majority (70\%) of the farmers were faced with production risks in relation to low yields. Lack of access to credit facilities was a major threat to farmers as they had limited capital and could not expand their production due to lack of financial support from banks because of lack of collateral (68.3\% )(Table 5).

Table 5. Problems faced by vegetable farmers

\begin{tabular}{llll}
\hline Challenge & Frequency & Total & Percentage (\%) \\
\hline Lack of skills and training & 33 & 60 & 55 \\
High costs and limited access to inputs & 41 & 60 & 68.3 \\
Lack of reliable water facilities & 45 & 60 & 75 \\
Increase in global food prices & 44 & 60 & 73.3 \\
Inadequate agricultural extension services & 42 & 60 & 70 \\
Production risks in relation to low yields & 42 & 60 & 70 \\
Lack of access to credit facilities & 41 & 60 & 68.3 \\
\hline
\end{tabular}

The challenges faced by the farmers are similar to those previously reported (Dlamini \& Masuku, 2013; Xaba \& Masuku, 2013; Musi et al., 2018). There is need then going forward to find solutions to the challenges in order to increase profitability while moving the Kingdom towards the sustainable development goals (SDGs).

\section{Conclusion}

Various factors affecting profitability of vegetable production for farmers in the Shiselweni region were investigated. Data was obtained through questionnaires and interviews with vegetable farmers. Collected data was analyzed using SPSS software where it was revealed that the average age of farmers was 50.5 years and average farming experience of three years. A family had an average of eight members. Most of the farmers were educated up to high school level and their average farm size was about three hectares. From the analysis it was shown that vegetable production in the Shiselweni region was profitable and that it was affected by various factors which included land size, gender and household size. Where applicable subsidized farm inputs should reach the farmers timely and that loans should be availed to farmers without stringent collateral security. It may be concluded that there is need to optimize vegetable production for maximum possible profits while striving to achieve the sustainable development goals (SDGs) in the Kingdom of Eswatini.

\section{Recommendations}

Based on the findings of the study, the following recommendations were made:

Having sufficient capital to begin the production process is key to improving profitability, therefore, it is recommended that smallholder vegetable farmers should be granted access to financial services. It is recommended that farmers are taught more of market forces economics and reduce their reliance on farm input handouts from government.

\section{References}

Blackwood, D. L., \&. Lynch, R. G. (1994). The measurement of inequality and poverty. World Development, 


\section{2(4), 567-578. https://doi.org/10.1016/0305-750X(94)90112-0}

Bonti-Ankomah, S. (2001). Addressing food insecurity in South Africa. South African Regional Poverty Network Conference on: Land Reform and Poverty Alleviation in South Africa. Pretoria.

Brodal, G., \& Asdal, A. (2018). The Svalbard global seed vault and the ongoing 100 years seed storage experiment. Acta Horticulturae, 1204, 1-8. https://doi.org/10.17660/ActaHortic.2018.1204.1

Connely, L.M. (2008). Pilot studies. Medsurg Nursing, 17(6), 411-412.

Dlamini, M. B., \& Masuku, M. B. (2013). Profitability of smallholder sugarcane farming in Swaziland: The case of Komati downstream development programme (KDDP) sugar farmers' associations, 2005-2011. Sustainable Agriculture Research, 2(1), 8-14. http://dx.doi.org/10.5539/sar.v2n1p8

Dlamini, S., Rugambisa, J. I., Masuku, M. B., \& Belete, A. (2010). Technical efficiency of the small-scale sugarcane farmers in Swaziland: A case of Vuvulane and Bigbend farmers. African Journal of Agricultural Research, 5(9), 935-940

Eigenbrod, C., \& Gruda, N. (2015). Urban vegetables for food security in cities, A review. Agronomy for Sustainable Development, 35(2), 483-498. https://doi.org/10.1007/s13593-014-0273-y

FAO. (2008). Climate Change and food Security: A Framework document, Rome, Italy

Government of Swaziland (2005). Comprehensive Agriculture Sector Policy. Mbabane, Swaziland.

George, R. A. T. (1999). Vegetable Seed Production. $2^{\text {nd }}$ Edition. CAB International, Wallingford, Oxon, UK

Gomez, K. A., \& Gomez, A. A. (1984). Statistical Procedures for Agricultural Research. $2^{\text {nd }}$ Edition. John Willey \& sons, New York, Singapore

Krejcie, R.V., \& Morgan, D. W. (1970). Determining sample size for research activities. Educational. Psychology. Measurement, 30, 607-610. https://doi.org/10.1177/001316447003000308

Lan, H., \& Dobson, P. W. (2017). Healthy competition to support healthy eating? An investigation of fruit and vegetable pricing in UK supermarkets. Journal of Agricultural Economics, 68(3), 881-900. https://doi.org/10.1111/1477-9552.12241

Lavsque, R. (2007). SPSS Programming and Data Management: A Guide for SPSS and SAS Users. ( ${ }^{\text {th }}$ Edition), Chicago, Illinois, USA

MacDonald, M. B., \& Copeland, L. O. (1998). Seed Production: Principles and Practices. Chapman and Hall Inc., New York, New York, USA.

Manyatsi, A. M., Mhazo, N., \&.Masarirambi, M. T. (2010). Climate variability and change as perceived by rural communities in Swaziland. Research Journal of Environmental and Earth Sciences, 2(3), 165-170.

Manyatsi, A. M., Thomas, T. S., Masarirambi, M. T., Hachingonta, S., \& Sibanda, L. M. (2013). Southern African agriculture and climate change: A comprehensive analysis- Swaziland. In: Hachingonta S., Nelson, G. C., Thomas, T. S. \& Sibanda, L. M (Eds). Southern African agriculture and climate change: A comprehensive analysis. International Food Policy Research Institute (IFPRI), Washington, DC, USA

Masarirambi, M. T., Mbokazi, B. M.. Wahome, P. K., \& Oseni, T. O. (2012a). Effects of kraal, chicken, manure and inorganic fertilizer on growth and yield of lettuce (Lactuca sativa var Commander) in a semi-arid environment. Asian Journal of Agricultural Sciences, 4(1), 58-64.

Masarirambi, M. T., Sibandze, N., Wahome, P. K., \& Oseni, T. O. (2012b). Effects of kraal manure application rates on growth and yield of wild okra (Corchorus olitorius L.) in a sub-tropical environment. Asian Journal of Agricultural Sciences, 4(1), 89-95.

Masarirambi, M. T., Dlamini, P., Wahome, P. K., \&. Oseni, T. O. (2012c). Effects of chicken manure on growth, yield and quality of lettuce (Lactuca sativa L.) 'Taina' under a lath house in a semi-arid sub-tropical environment. American Eurasian Journal of Agriculture and Environmental Sciences, 12(3), 399-406

Musi, P. J., Mdluli, B. S., \& Masarirambi, M. T. ( 2018). Agribusiness opportunities, constraints and challenges facing the youth in Swaziland. American Eurasian Journal of Agriculture and Environmental Sciences, 18(3), 50-56.

Masuku, M. B. (2011). Determinants of sugarcane profitability: The case of smallholder growers in Swaziland. Asian Journal of Agricultural Sciences, 3(3), 210-214.

NAMBoard (2016). Annual Report for National Agricultural Marketing Board, Manzini, Swaziland. 
Norman, J. C. (1992). Tropical Vegetable Production. Arthur H. Stockwell Ltd. Elms Court, Ifracombe, Devon, UK

Ojiewo, C., Keatinge, D. J. D. H., Hughes, J., Tenkouano, A., Nair, R., Varshney, R., Siambi, M., Monyo, E. Ganga-Rao, N. V. P. R., \& Silim, S. (2015). The role of vegetables and legumes in assuring food, nutrition, and income security for vulnerbale groups in Sub-Saharan Africa. World Medical Health Policy, 7(3), 1-12 https://doi.org/10.1002/wmh3.148

Oseni, T. O., \& Masarirambi, M. T. (2011). Effects of climate change on maize (Zea mays) production and food security in Swaziland. American-Eurasian Journal. Agriculture Environmental Science, 11(3), 385-391.

Panin, A., \& Hlophe, S. S. (2013). Does subsistence agriculture play a crucial role in food security in Swaziland?. Development Country Studies, 3(4), 32-36.

Peirce, L. C. (1987). Vegetables: Characteristics, Production and Marketing. John Wiley \& Sons Inc. New York, NY, USA.

Salkind, N. J. (2012). Exploring Research, $8^{\text {th }}$ Edition, Upper Saddle River, New Jersey, USA

Turner, M. (2010). Seeds. The Tropical Agriculturist, CTA, Wageningen, The Netherlands \& Macmillan Publishers Limited, Oxford, UK

Thompson, C. F. (2011). Swaziland Business Year Book. Christina Forsyth Thompson, Mbabane, Swaziland.

Van Dalen, D. B. (1979). Understanding Educational Research. New York: Macgraw Hill.

Wills, R. B. H., Li, Y., \& Golding, J. B. (2018). Maintaining the market life of vegetables held at an ambient tropical temperature by reducing exogenous ethylene. Tropical Agriculture (Trinidad), 95(1), 31-37.

Xaba, G. B., \& Masuku, M. B. (2013). Factors affecting the choice of marketing chanel by vegetable farmers in Swaziland. Sustainable Agricultural Research, 2(1), 212-220. http://dx.doi.org/10.5539/sar.v2n1p112

Yamaguchi, M. (1983). World Vegetables AVI, Westport, Connecticut, USA. https://doi.org/10.1007/978-94-011-7907-2

\section{Copyrights}

Copyright for this article is retained by the author(s), with first publication rights granted to the journal.

This is an open-access article distributed under the terms and conditions of the Creative Commons Attribution license (http://creativecommons.org/licenses/by/3.0/). 